\title{
Palju õnne!
}

\section{5}

6. veebruar

Olli (Olga Ottilie) Kõiva - folklorist

23. märts

Tiiu Salasoo - botaanik, pedagoogika- ja keeleteadlane, ajakirja Mäetagused toimetuskolleegiumi liige

80

9. jaanuar

Mall Hiiemäe - folklorist, Eesti Kirjandusmuuseumi Eesti Rahvaluule Arhiivi vanemteadur

5. veebruar

Luule Krikmann - filoloog, kauane Mäetaguste keeletoimetaja

75

8. aprill

Kristi Salve - folklorist

70

11. veebruar

Igor Tõnurist - etnoloog ja rahvamuusik

23. mai

Rein Saukas - folklorist 
UUDISED

\section{5}

2. märts

Janīna Kursīte - Läti kirjandusteadlane, ajakirja Mäetagused toimetuskolleegiumi liige

60

9. veebruar

Merike Kiipus - Eesti Kirjandusmuuseumi Arhiivraamatukogu juhataja

17. juuli

Vilve Asmer - Eesti Kirjandusmuuseumi Eesti Kultuuriloolise Arhiivi juhataja

\section{5}

25. august

Ülo Valk - Tartu Ülikooli kultuuriteaduste ja kunstide instituudi juhataja, ajakirja Folklore: Electronic Journal of Folklore toimetuskolleegiumi liige

45

22. august

Mari Sarv - Eesti Kirjandusmuuseumi Eesti Rahvaluule Arhiivi vanemteadur

40

24. aprill

Andreas Kalkun - Eesti Kirjandusmuuseumi Eesti Rahvaluule Arhiivi teadur 


\section{Kroonika}

\section{Akadeemilises Rahvaluule Seltsis}

26. oktoobril pidas kõnekoosolekul ettekande Jazmina Cininas (The Girlie Werewolf Hall of Fame: historical and contemporary figurations of the female lycanthrope). Jaan Sudak esitles oma raamatut "Luupainajad Kihnu rahvausundis".

30. novembril esinesid Akadeemilise Rahvaluule Seltsi 15. sügiskonverentsil "Välitööd väärtuste skaalal” Mall Hiiemäe (Ood osalusvaatlusele), Anu Korb (Siberi välitööpäevikud arhiivis ja valikutest nende publitseerimisel) ja Mare Kalda (Meemimered ja viraliväljad. Internetimeemid rahvaluulekoguja töölaual(e)) Eesti Kirjandusmuuseumist, Madis Arukask, Eva Saar ja Käbi Suvi (Välitööd Venemaa keelesugulaste juures: muutuvad olud, püsivad väärtused?) ning Anastasiya Fiadotava (Etic and Emic Approach to Values in Humour Research Fieldwork) Tartu Ülikoolist, Marika Alver ja Liina Lepik (Terroristid või ususekt: Eesti Kunstiakadeemia ekspeditsioon 1949. aastal küüditatute jälgedes Siberisse) Eesti Kunstiakadeemiast, Hanna-Maria Mets, Marija Toomjõe, Rauno Juntson ja Karl-Johannes Kõiv (Välitööpraktika Mõnistesse ja Setumaale) Hugo Treffneri Gümnaasiumist ning Valgevene teadlane Alena Leshkevich (Researching Calendar Holidays in Modern Belarus: Traditional Festivals, Performative Practices and Intangible Cultural Heritage).

Kärri Toomeos-Orglaan

\section{Eesti Rahvaluule Arhiivis}

2. augustil intervjueeris Jüri Metssalu Juuru kihelkonnas Ingliste pensionäride koosolekul osalejaid Ingliste kohapärimuse artikli koostamiseks.

4. augustil toimus loengusarja "ERA tuleb külla" üritus Saaremaal. Viki külas Mihkli Talumuuseumis esinesid Mari Sarv (Mis lugu rahva mälestustest pidada: rahvaluulekogude tähtsus ja tähendus), Risto Järv (Unes nähtud varandus - ehk mönda Saaremaa rahvajuttudest), Taive Särg (Kihelkonna ja selle ümbruse rahvamuusikast ERA kogudes) ning Mall Hiiemäe (Kalakull ja teised endelinnud rahvausundis). Üritus toimus koostöös Saaremaa Muuseumi Mihkli Talumuuseumiga.

4. augustil pidas Janika Oras Alar Krautmani Terviseakadeemia loodusravipäevadel Joaveskil loengu eesti loitsude esitamisest ja viis läbi õpitoa regilauludest.

9. augustil toimus Tallinnas Eesti Keele Instituudis (Roosikrantsi 6) Eesti-uuringute Tippkeskuse ajalooliste väljendus- ja kultuuripraktikate uuringute töörühma seminar "Humanitaarteaduste roll rahvuse (de)konstrueerimise protsessis"; ERA poolt osales seminari korraldamises Mari Sarv.

10. augustil tutvustas Jüri Metssalu Rapla kihelkonnas Tarsi talu pärimuskultuuri suvekoolis "Esivanemate jälgedes” ümbruskonna pärimuspaiku. 
11. augustil Paides toimunud arvamusfestivalil osales Mari Sarv Eesti Rahvusringhäälingu ja Eesti Rahvaluule Arhiivi korraldatud arutelus "Kuidas mäletada, kuidas kujutada - kultuurimälu talletamine ja rahvusidentiteedi kujundamine", kus käsitleti mäluasutuste rolli Eesti ühiskonnas, kultuurimälu talletamist ja selle kasutamist ühiskondliku sidususe loomisel ning rolli rahvusidentiteedi kujundamisel.

12. augustil toimus loengusarja "ERA tuleb külla" üritus Lääne-Virumaal. Pajusti klubis esinesid Kadri Tamm (Eesti Rahvaluule Arhiiv oma 90. sünnipäeva lävel. Mida on meil pakkuda ja mida loodame koguda) ning Anu Korb (Tomski oblasti eestlastelt kogutu Eesti Rahvaluule Arhiivis).

13.-16. augustil õpetas Janika Oras vadjakeelseid laule ja laulumänge Heinike Heinsoo korraldatud vadja keelekursustel osalejatele Vadja muuseumis Luutsa külas (Venemaa, Leningradi oblast, Kingissepa rajoon).

15. augustil kõneles Jüri Metssalu Luige Kandikeskuse rabamatkal kohapärimusest ja pühapaikadest.

17. augustil kõneles Mall Hiiemäe lindudega seotud uskumustest ettekandes "Traditional beliefs related to birds" Haapsalu keskkonnaametis linnukaitse ettekandepäeval, mis toimus rahvusvahelise noortevahetuse programmi raames.

18. augustil tutvustas Janika Oras eesti lõikuslaulude traditsiooni rukkimaarjapäeva tähistamisel Eesti Põllumajandusmuuseumis.

20. augustil võttis Janika Oras Valgas osa Valgamaa pärimuskultuuri peost "Eesti pulm" mõrsjapoolsete laulikuna (korraldaja Valgamaa Muuseum) ning intervjueeris septembris teisi laulikuid.

23.-25. augustini pidas Janika Oras Lummo Kati laululaagris Nedsaja külas Setomaal loengu seto leelost, viis kolmel päeva läbi seto leelo õpitube ja salvestas vestlusõhtutel seto laulikute tütarde mälestusi ja laulmist, samuti Helmise leelokoori kontserti. Samas laagris õpetas seto laule ka Andreas Kalkun.

Augustis tegid Jüri Metssalu, Mari-Ann Remmel, Valdo Valper ja Reeli Reinaus välitöid Rapla, Hageri ja Jüri kihelkonna looduslikes pühapaikades.

7. septembril tutvustas Janika Oras Tallinnas Kodanikuühiskonna Sihtkapitali EV100 toetuse saajate seminaril kolme regilaulude väljaande "Vana kannel" avaldamise projekti.

9. septembril esines Mall Hiiemäe ettekandega "Kodukandi paigad ja pärimus. Rakvere valla suuline ajalugu ERA rahvaluulekogus”Viru Instituudi rahvapärimuse päeval Karitsas.

14. septembril esines Jüri Metssalu Tallinnas Rahvakultuuri Keskuse Eesti Vabariigi 100. sünnipäevale pühendatud loengusarjas "Eestlaste mõtteilm" loenguga "Pärimusmaastik meis ja meie ümber".

15. ja 16. septembril võttis Taive Särg osa rahvamuusika- ja pärimusmuusika õpetajate erialapäevadest Mooste Rahvamuusikakoolis. Ta pidas ettekande "Rahvamuusika ja pärimusmuusika - eesti keeles ja muusikas", juhtis laulmise ja ringmängude teemalist jututuba ning helisalvestas arutelusid. 
25.-28. septembrini toimus Eesti Kirjandusmuuseumis ERA 90 sünnipäevakonverents "Archives as Knowledge Hubs: Initiatives and Influences" (Arhiivid kui teadmiste teejaamad: mõtteid ja mõjusid). Ühe kolmest plenaarettekandest pidas ERA vanemteadur Mall Hiiemäe (Arhiiv kui teadmuskeskus), ERAst esinesid veel Ave Goršič (On some turning points in the history of the Estonian Folklore Archives), Risto Järv (A grain a day: The digital visibility of the Estonian Folklore Archives), Liina Saarlo (Kalevipoeg as the saviour of Estonian folkloristics in the 1950s), Mari Sarv (Folklore collections in the service of Estonian society: Integrity in diversity) ning Taive Särg (The archives: Visible and invisible. The role of the Estonian Folklore Archives in the processes of folk music in the early 21st century). Konverentsi avapäeval esitleti ajakirja Mäetagused Virumaa erinumbreid 66 ja 67 (külalistoimetaja Mall Hiiemäe, valminud koostöös Viru Instituudiga), ajakirja Folkore: Electronic Journal of Folklore regilauluerinumbreid 67 ja 68 (külalistoimetaja Janika Oras) ning Helen Kõmmuse koostatud heli- ja videoväljaannet "Hiiumaa rahvalaulud, pillilood ja tantsud". Eesti Kirjandusmuuseumi trepigaleriis avati Aivo Põlluääre koostatud näitus "Fototerad", mis tugineb rahvaluule arhiivi Facebooki-lehel ja Instagramis ilmunud postitustele ehk erateradele, ning esimese korruse galeriis Reet Hiiemäe näitus arhiivimaterjalide tsenseerimisest. Muusikalist meelelahutust pakkus postfolk-duo Puuluup. Konverentsi korraldas rahvaluulearhiiv koostöös Põhja- ja Baltimaade pärimusarhiivide võrgustiku ja Eestiuuringute Tippkeskusega, peakorraldajad olid Ave Goršič, Risto Järv ja Mari Sarv.

25.-28. septembrini pidas Andreas Kalkun Riias Läti Ülikoolis loengukursuse seto kultuurist.

28. septembril osales Risto Järv teadlaste öö raames Eesti Kirjandusmuuseumi saalis juturingis moraalist, eetikast ja tulevikust vaimolendite pilgu läbi.

29. septembril pidas Janika Oras Krakovis (Poola) Jagiellonia Ülikooli tsivilisatsioonide võrdlevate uuringute keskuses toimunud rahvusvahelisel konverentsil "Feast as a Mirror of Social and Cultural Changes" ettekande pulmalaulikute rollist ja performatiivsusest (Roles and performativity of the singers in Estonian historical and revived traditional weddings).

29. septembril esines Mari Sarv Tallinna Ülikoolis rahvusvahelisel värsimõõdu alasel konverentsil "Frontiers in Comparative Metrics III" ettekandega ideoloogiate mõjust regilaulu värsimõõdu interpreteerimisel (Ideological interpretations of Estonian runosong meter: Research and literary use).

30. septembril kõneles Jüri Metssalu Rapla Vesiroosi Gümnaasiumi keskkonnaklubi vilistlaste nostalgiamatkal Kuimetsa Iida urgete ja Paluküla Hiiemäe pärimuslikust olemusest.

2. oktoobril alustas uut hooaega elulookirjutajate ring. 2010. aastast kooskäiva rühmaga liitusid sel aastal ka rahvaluule arhiivi kaastöölised. Rühma veavad Rutt Hinrikus, Tiina Ann Kirss ja ERAst Astrid Tuisk.

4.-6. oktoobrini Narvas korraldatud seitsmendal rahvusvahelisel noorte folkloristide konverentsil "Negatiations and Belonging" (Kuulumise ja eristumise praktikad) pidas Aivo Põlluäär ettekande kollektiivtööst saarlaste elulugudes (Collective Work as a Marker of Continuity in the Life Stories of Collective Farmers of the Viktor Kingissepp Kolkhoz 
in Saaremaa, Estonia) ning Lona Päll ettekande kuuluvus- ja võõrandumistundest lugudes Kakerdaja rabast (Belonging and Alienation in Stories about the Kakerdaja Bog).

5. oktoobril esines Ingrid Rüütel ettekandega "Muhu laulud ja lood" Tallinna Tehnikaülikooli eakate ülikoolis.

6. oktoobril esinesid loengusarja "ERA tuleb külla" raames Kärdlas Hiiumaa Muuseumis Astrid Tuisk (Eesti Rahvaluule Arhiiv 90. Mida on meil pakkuda ja mida loodame koguda), Mari Sarv (Rahvaluulekogude tähtsus ja tähendus Eesti loos), Risto Järv (Hiiumaa giididelt pärimust kogumas) ning Helen Kõmmus (Hiiumaa rahvamuusika mõistatused, üllatused ja avastused). Esitleti CD-DVD kogumikku "Hiiumaa rahvalaulud, pillilood ja tantsud”. Ettekandepäev korraldati koostöös Hiiumaa Muuseumiga.

9. oktoobril tutvustas Jüri Metssalu Tartu Ülikooli Viljandi Kultuuriakadeemia kohapärimuse loengukursuse raames tudengitele ERA ja Tartu Ülikooli arheoloogia kabineti kogusid.

11. oktoobril kohtusid Risto Järv, Mari-Ann Remmel ja Jüri Metssalu Tallinnas Keskkonnaameti esindajate Kaja Lotmani ja Ave Paulusega Eesti Kirjandusmuuseumi ja Keskkonnaameti koostöölepingu loomiseks. Leping allkirjastati 7. novembril.

12. oktoobril pidas Janika Oras Leedus, Vilniuse Ülikooli ajalooteaduskonnas rahvusvahelisel konverentsil "Traditsiooniline kultuur haridussüsteemis ja kultuuriturismis. Eri maade kogemus" ettekande "Kohaliku seto mitmehäälse laulukultuuri õpetamine Eesti erinevates õppeasutustes".

12. oktoobril kõneles Jüri Metssalu Tre Raadio hommikuintervjuus kohapärimuse õpetamisest, pärimusmaastiku olemusest, looduslike pühapaikade uurimisest ja kaitsmisest.

14. oktoobril esines Jüri Metssalu Eesti Kohapärimuse Keskuse sügisseminaril ettekandega Rapla ja Hageri looduslike pühapaikade uuringust.

14. oktoobril võtsid Ingrid Rüütel ja Taive Särg osa III rahvamuusikatöötluste festivali Folgi Krõmps žürii tööst Pärnu Muuseumis ning tutvustasid festivali kohustuslikku lugu oma ettekannetes "Laulust hobu” (I. Rüütel) ning “Heinast hobu. Krõõt Lillestern”(T. Särg).

16. oktoobril arutleti Eesti Rahvaluule Arhiivi siseseminaril arhiivi kogumispoliitikate, tulevaste kogumisaktsioonide ning arhiivi avaliku kuvandi kujundamise üle.

17. oktoobril esinesid loengusarja "ERA tuleb külla" raames Ida-Virumaal Iisaku Kihelkonna Muuseumis Anu Korb (Virumaa rahvaluule kogumine ja kogujad), Risto Järv (Virumaa tõsiloolised muinasjutud) ja Mall Hiiemäe (Linnud Alutaguse maastikul ja uskumustes). Esitleti ajakirja Mäetagused Virumaa erinumbreid (66 ja 67). Loengupäev toimus koostöös Iisaku Kihelkonna Muuseumi ja Viru Instituudiga.

20. oktoobril esinesid loengusarja "ERA tuleb külla" raames Jõgeval Betti Alveri Muuseumis Liina Saarlo (Eesti rahvaluulekogud arhiivis ja internetis), Kristi Salve (Kirikhärra ja rätsep. Kaks Laiuse rahvaluulekogujat) ja Astrid Tuisk (Andmebaasid ja kogumine: rahvaluulearhiiv tänapäeval). Üritus toimus koostöös Betti Alveri muuseumiga. 
24. oktoobril pidas Inge Annom Riias Läti mustlaste uurijate seminaril ettekande 1930. aastatel Lutsimaa mustlastelt kirja pandud juttudest (Roma people and their folktales in the Ludza region of the 1930s).

26. oktoobril pidas Risto Järv Taanis, Kopenhaagenis konverentsil "Mermaids, Maritime Folklore, and Modernity" (Merineitsid, merefolkloor ja modernsus) ettekande "Diver Niglas and the Mermaids: "An Ancient Tale of the Estonian People"' (Sukelduja Niglas ja merenäkid: "Eestirahva ennemuistene jut").

30. ja 31. oktoobril osales Ave Goršič Riias Krisjāṇs Baronsi mälestuskonverentsil "Folklora: vērtības un intereses" (Folkloor: väärtused ja huvid) ettekandega rahvameditsiini hingest (Tautas ārstniecības "garu" meklējot).

31. oktoobril toimus Eesti Kirjandusmuuseumis ümarlaud Tartu Ülikooli intellektuaalse omandi õiguste professori Aleksei Kelliga, kus käsitleti ERA materjalide kogumise, avaldamise ja kasutamisega seotud õiguslikke küsimusi.

1.-3. novembril toimus Eesti Rahva Muuseumis ja Eesti Kirjandusmuuseumis viies Eesti digihumanitaaria konverents "Avatud litsentsid, avatud sisu ning avaandmed digihumanitaaria arendamise võimalusena". Rahvusvahelise konverentsi eesmärk oli kaasata teadusdiskussiooni varasemast enam mäluasutusi, kellel on humanitaarteaduste valdkonnas oluline roll uurimisainese haldajana ning avalikkusele vahendajana. Konverentsi peakorraldajateks olid Wikimedia Eesti ning Eesti Digitaalhumanitaaria Selts ning see kuulus Eesti Euroopa Liidu eesistumise ürituste programmi. Konverentsiga oli integreeritud töötubade programm ja doktorikooli moodul, mida kaaskorraldasid keeleteaduse, filosoofia ja semiootika doktorikool (KFSDK) ja Eesti Kirjandusmuuseumi ASTRA projekt EKMDHUM. ERA poolt osales konverentsi ja doktorikooli mooduli korraldamisel Mari Sarv.

1. ja 2. novembril pidas Astrid Tuisk Eesti Kirjandusmuuseumis ja Eesti Rahva Muuseumis korraldatud lasteaiaõpetajate seminaril "Mäng on väikese inimese töö" ettekande "Laste sõjamängud ajaloolis-kultuurilises kontekstis" ning Janika Oras viis läbi õpitoa vanematest laulumängudest "Laulumängu rõõm ja saladused".

3. novembril toimus loengusarja "ERA tuleb külla" üritus Setumaal. Värskas Seto Tsäimajas esinesid Andreas Kalkun (Setode "avastamisest" ja seto rahvaluule kogumise algusest), Kärri Toomeos-Orglaan (Kirillitsas kirja pandud seto jutusõ') ning Inge Annom (Lutsi maarahvast).

9. novembril kõneles Taive Särg Tallinnas Rahvakultuuri Keskuse Eesti Vabariigi 100. sünnipäeva loengusarja "Eestlaste mõtteilm" raames teemal "Pärimus muusikas".

10. novembril toimus loengusarja "ERA tuleb külla" üritus Viljandimaal Mulke sügüskuuli 2017 esimese osana. Kärstna mõisas esinesid Risto Järv (Eesti Rahvaluule Arhiivist ja eesti rahva muinasjuttudest), Inge Annom ("Hundi patutunnistus". Žanripiirid loomamuinasjuttudes), Kärri Toomeos-Orglaan (Naise tegelaskujust Eesti imemuinasjuttudes) ja Rein Saukas (ettekanded "Jakob Hurda kaastöölised Tarvastu ja Helme kihelkonnas" ning "Vanasõnu ja mõistatusi”). Päev toimus koostöös Mulgi Kultuuri Instituudiga. 
10. novembril oponeeris Aado Lintrop Tartu Ülikoolis Nikolai Anisimovi doktoritööd "Maailmadevaheline dialoog udmurtide kommunikatiivse käitumise matriitsis".

11. novembril esinesid Setomaal Meremäe turismitalus toimunud Leelokonverentsil Janika Oras (Vanamoodi laulmine ja teistmoodi õppimine) ja Andreas Kalkun (Seto aolugu seto lauluh).

13. novembril pidas Taive Särg ajakirja Journal of Ethnology and Folkloristics (JEF) 10. aastapäeval Tartu Ülikoolis ettekande "Emakeelne teadus, rahvusvaheline teadlaskond ja terviklik rahvuskultuur / Research in the Mother Tongue, the International Scholarly Community and the Unity of National Culture".

13. novembril pidas Risto Järv Suurbritannias, Londonis sümpoosionil "Digital cultural heritage: FUTURE VISIONS LONDON 2017” ettekande Eesti kohapärimuse kaardirakendusest (Estonian Place-Lore on a Digital Map).

14. novembril toimus loengusarja "ERA tuleb külla" teine üritus Viljandimaal. Kolga-Jaani põhikoolis esinesid Janika Oras (Kolga-Jaani kuulsused Eesti Rahvaluule Arhiivis), Astrid Tuisk (ERA tänapäeval: andmebaasid ja rahvaluule kogumine), Säde Tatar (Julged unistused) ning Aado Lintrop (Üks mansi jutt ERA soome-ugri kogudest).

17. novembril esinesid Tartumaal Rupsi külas Liivi muuseumis loengusarja "ERA tuleb külla" raames Ave Goršič (Killukesi ERA ajaloost), Liina Saarlo (Rahvaluulekogud kogukonnale: Kodavere veebivärav), Mall Hiiemäe (Lõevuke, piäske ja teised linnud Kodavere rahvapärimuses) ja Astrid Tuisk (Lapsepõlv, mängud ja mängimine). Üritus toimus koostöös Liivi Muuseumiga.

18. oktoobri kõlas Helen Kõmmuse intervjuu Vikerraadio saatesarjas "Hiiukeelsed uudised", kus ta rääkis ilmunud CD-DVD-kogumikust "Hiiumaa rahvalaulud, pillilood ja tantsud".

24. novembril esinesid loengusarja "ERA tuleb külla" raames Järvamaal Paide raekojas Risto Järv (Eestimaa südamest ja rahvaluulearhiivist), Mari-Ann Remmel (Meenutusi Järvamaa kohapärimuse teekonnast arhiiviandmebaasi ja raamatusse), Liina Saarlo (Rahvaluulekogud kogukonnale: Kesk-Eesti pillilugude ja Peetri regilaulude veebiväravad) ja Janika Oras (Kohtumised laulumaailmades). Üritus toimus koostöös SA Ajakeskus Wittensteini / Järvamaa Muuseumiga.

24. novembril pidas Andreas Kalkun Obinitsa muuseumitares rahvariidekoolitusel ettekande seto naiste traditsioonilistest peakatetest.

25. novembril osalesid Ave Goršič ja Mari Sarv Iirimaal, Dublinis korraldatud konverentsil "Irish Conference of Folklore and Ethnology 2017" ettekandega Soome mõjudest Eesti rahvaluuleteadusele (Finnish imprints on Estonian folklore studies: methods, models, contrabands).

29. novembril esinesid loengusarja "ERA tuleb külla" raames Rapla kultuuriklubis BAAS Kadri Tamm (Matthias Johann Eisen ja tema rahvaluulekogu), Ave Goršič (Killukesi ERA ajaloost), Mari Sarv (ERA virtuaalsed sisse- ja väljapääsud), Jüri Metssalu 
(Meeleolukaid momente ERA kohapärimuse töörühma välitöödelt) ja Mall Hiiemäe (Hingedeaeg meie looduses ja rahvapärimuses). Ettekandeõhtu toimus koostöös Eesti Kohapärimuse Keskusega.

29. novembril esines Ingrid Rüütel Rakvere teatris vestlusõhtul Virumaa keelest ja kultuurist.

30. novembril Eesti Kirjandusmuuseumis toimunud Akadeemilise Rahvaluule Seltsi 15. sügiskonverentsi "Välitööd väärtuste skaalal" üks korraldajaid Anu Korb pidas konverentsil ettekande "Siberi välitööpäevikud arhiivis ja valikutest nende publitseerimisel", Mall Hiiemäe pidas ettekande "Ood osalusvaatlusele".

Risto Järv, Mari Sarv

\section{Eesti Kirjandusmuuseumi folkloristika osakonnas}

Eesti Välisministeeriumi arengu-ja humanitaarabi vahendite, Euroopa Regionaalarengu Fondi (Eesti-uuringute Tippkeskus TK 145) ja Eesti Teadusagentuuri projekti IUT 22-5 toel osalesid osakonna töös järgmised Valgevene teadlased:

1.-30. juunini Yanina Hrynevich ja Irina Vasilyeva;

1.-28. juulini Aliaksandra Shrubok;

1.-11. augustini Iryna Smirnova ja Siarhei Vyskvarka;

10.-31. augustini Alena Bohaneva;

1.-30. septembrini Juras Paciupa;

24.-29. septembrini Yanina Hrynevich ja Irina Vasilyeva;

1.-31. oktoobrini Alaksei Hlushko ja Anastasia Hlyshkova;

1. novembrist 1. detsembrini Alena Leshkevich;

4.-10. detsembrini Nikolaj Antropov (toetus ka Eesti Teaduste Akadeemialt);

6.-9. detsembrini Aliaksandra Shrubok (toetus ka Eesti Teaduste Akadeemialt);

4.-30. detsembrini Alena Bohaneva.

28. juunist 1. juulini osales Anneli Baran Grazis Karl Franzensi Ülikoolis projekti "Meteo-prognostic paroemias" seminar-töötoas.

29. juunist 2. juulini osales Mare Kõiva Moskvas V rahvusvahelisel interdistsiplinaarsel teaduslik-praktilisel sümpoosionil "Meditsiiniantropoloogia ebastabiilses globaliseeruvas maailmas", ta pidas seal ettekande "Курсы природной терапии и народной медицины в Эстонии" ja juhatas koos Marjam Kerimovaga sektsiooni "Rahvameditsiin, traditsiooniline meditsiin ja traditsioonilised meditsiinisüsteemid meditsiiniantropoloogia fookuses".

3.-6. juulini osalesid Mare Kõiva ja Andres Kuperjanov Udmurdi Vabariigis Iževskis XII Venemaa antropoloogide ja folkloristide kongressil. Sektsioonis "Etniliste vastasmõjude uurimise distsipliinidevahelised meetodid" esines Mare Kõiva ettekandega “Повелитель волков - обзор прибалтийско-финского материала" ја Andres Kuperjanov ettekandega “Сито в эстонской мифологии”, lisaks pidas Mare Kõiva meditsiiniantropoloogia sektsioonis ettekande rahvaravitsejatest 1980. aastate näitel. 
4.-7. augustini töötas Mare Kõiva välisvahetuses Riias Läti rahvusraamatukogus.

5. augustil pidas Reet Hiiemäe Joaveskil Alar Krautmani Terviseakadeemia korraldatud loodusravi päevadel loeng-töötoa "Kaitsemaagia eesti rahvapärimuses".

16.-22. augustini jälgisid Andres Kuperjanov ja Mare Kõiva Valge Vennaskonna suurlaagrit ja Paneurythmia toimumist Sofias, Rila mäestikus (Bulgaaria).

17. augustil pidas Reet Hiiemäe koos Mall Hiiemäega Haapsalu keskkonnaametis noortevahetuse noortele loengu "Linnud eesti pärandkultuuris".

3.-6. septembrini toimus Minskis koolitusseminar ning 5. septembril Eesti Kirjandusmuuseumi folkloristika osakonna ja Valgevene TA kultuuri keele ja kirjanduse uurimise keskuse kunstiteaduste, etnograafia ja folkloori filiaali ühiskonverents "Mission possible. Folkloori uurimise perspektiivid 3". Esinesid Nikolay Kuznetsov (Maailmaloomine komi mütoloogias), Tatjana Volodina (Fraseoloogia ja maagilised praktikad kosmogooniliste legendide kontekstis (valgevene pärimus)), Piret Voolaid (Naljaküsimuste uus visuaalne elu internetimeemides), Eda Kalmre (Tütarlaste käsikirjalised armujutud: ajalugu ja areng), Liisi Laineste (Kaasaegne tütarlaps eesti karikatuurides sõdade vahel (aastad 1920-1939)), Andres Kuperjanov (Sõel religioosses pärimuses), Mare Kõiva (Lilleoru - uus elulaad ja religioon), Alena Bohaneva (Mõningaid ühisjooni valgevene ja eesti mütoloogilistes ja rahvausundi tegelaste puhul), Katre Kikas (Rahvaluule kogumise kampaaniatest 1890. aastatel. Mis motiveeris mitteprofessionaalsed kogujaid), Tõnno Jonuks (Soome ja Eesti pühakohtade panustest) ja Reet Hiiemäe (Mittekohad pühakoha rollis).

8.-23. septembrini viibis Mare Kõiva välisvahetuses Ljubljanas, Sloveenias.

19. septembril kogunes seminarile Eesti-Uuringute Tippkeskuse nüüdiskultuuri töörühm, mida sellest sügisest koordineerib Saša Babič. Arutati nii korralduslikke kui ka sisulisi küsimusi: missuguste teemadega uurijad tegelevad, missugustele tänapäevastele ühiskondlik-kultuurilistele ilmingutele tuleks veel tähelepanu pöörata.

29. septembril korraldas Reet Hiiemäe Eesti Kirjandusmuuseumis teadlaste öö vestlusringi "Moraal, eetika ja tulevik kummitus- ja hirmuolendite pilgu läbi" ning koostas kirjandusmuuseumi fuajeevitriinidesse näituse "Tsensuur läbi aja”.

29. septembril osales Reet Hiiemäe folkloristi kommentaariga lühifilmisarja "Pärimusklipp" lühifilmis "Pärimusklipp - luupainaja".

30. septembril esines Reet Hiiemäe TÜ Viljandi Kultuuriakadeemia üritusel "Pärandtehnoloogia sügiskool - tulest tulnud" loenguga "Tuli maagias ja uskumustes".

13. oktoobril esines Eesti-uuringute Tippkeskuse nüüdiskultuuri töörühma seminaril Saša Babič, teemaks blondiininaljad.

20. oktoobrist 3. novembrini viibisid Bulgaarias välisvahetuses Mare Kõiva ja Andres Kuperjanov.

25.-28. oktoobrini osales Katre Kikas Eesti Rahvaluule Arhiivi konverentsil, kus pidas ettekande "A voice from the margins of archive and society: Hans Anton Schults". 
4. oktoobril andis Reet Hiiemäe TV3 "Seitsmestele uudistele" folkloristi kommentaari käsikirjade tsenseerimise ja näituse "Tsensuur läbi aja" kohta.

9.-11. oktoobrini osalesid Andres Kuperjanov ja Mare Kõiva Vilniuses konverentsil "Balkan and Baltic states in united Europe: history, religion, and culture III". Andres Kuperjanov pidas ettekande "Sacral, cultural and memoriaal places related to water" ja Mare Kõiva ettekande "Inventing sacrality".

13. oktoobril esines Saša Babič Eesti Kirjandusmuuseumis Eesti-uuringute Tippkeskuse (CEES) seminaril: "Truth about blondes: how funny is it?".

27. ja 28. oktoobril osales Piret Voolaid Käärikul Tartu Ülikooli keeleteaduse ja tõlkeõpetuse magistrikooli sügiskoolis loenguga "Folkloori lühivormid - keelest meeleni ja meelest keeleni” ja juhtis töötuba Eesti Kirjandusmuuseumi folklooriandmebaasidest.

30. ja 31. oktoobril osalesid Sofias (Bulgaaria) konverentsil "Between the Worlds: People, Spaces and Rituals" ettekannetega Reet Hiiemäe (Zombies, aliens and the slenderman: supernatural beings in the contemporary children's lore), Mare Kõiva (The Time of Wooden Gods) ja Andres Kuperjanov (20 years of Open Access).

1. ja 2. novembril toimus Tartus Eesti Kirjandusmuuseumis ja Eesti Rahva Muuseumis lasteaiaõpetajate eesti keele õppeseminar "Mäng on väikese inimese töö", mille peakorraldaja oli osakonna vanemteadur Piret Voolaid.

2. novembril pidas Reet Hiiemäe Eesti Folkloorinõukogu pärimuskultuuri kogemuspõhisel koolitusel ettekande "Traditsiooniline tähtpäevakombestik tänapäevases sügistalviste tähtpäevade ja pühade tähistamises. Improvisatsioon traditsioonis”.

4. novembril esines Mare Kõiva Pärnus rahvariiete ja rahvatantsu teemalisel konverentsil "Põlvest põlve" ettekandega "Värvid ja sümbolid" ning osales Urmas Vaino juhitud diskussioonis "Rahvarõiva kohanemine ja kohandumine".

17. novembril pidas Reet Hiiemäe Tabivere eakate seltsingule Lumeroos loengu "Eesti rahvatarkused ja sügistalvised tähtpäevad”.

20. novembril esines Saša Babič Ljubljana Ülikoolis loenguga sloveenia folkloori lühivormidest.

20. novembrist 20. detsembrini kestab koolipärimuse kogumisaktsiooni 2017/2018 piltootprojekt.

22. novembril esines Saša Babič Ljubljanas Sloveenia televisioonis, rääkides sloveenia vandesõnadest.

29. novembril viis Reet Hiiemäe Viljandi kultuuriakadeemias läbi loeng-seminari "Rahvausund ja kombestik tänapäeva maailmas ja Eestis".

1. detsembril viis Reet Hiiemäe Tartu Rahvusvahelise Maja välismaalastest liikmetele läbi loeng-töötoa "Pilguheit eesti usundisse: kaitsemaagia, kummitused ja tsensuur".

6. detsembril pidas Reet Hiiemäe Viljandi kultuuriakadeemias loeng-seminari "Kohalood ja paigapärimus ning nende kasutamise võimalusi tänapäeval”. 


\section{Teisipäevaseminarid}

30. augustil seminarisarja avaistungil "Rahvapiibli uurimine tänapäeva humanitaarteadustes. Eesti ja valgevene paralleele" oli lähema vaatluse all rahvapiibli määratlus, folkloorsete piiblite uurimisajalugu Lääne-Euroopas ja Ida-Euroopas 20. sajandi lõpus ja 21. sajandi alguses, aga ka žanrid ja põhiliigid ning põhilised teemad ja süžeed valgevene rahvapiiblis. Välisministeeriumi arengu- ja humanitaarabi programmi ning Euroopa Regionaalarengu Fondi (Eesti-uuringute Tippkeskus) toel esinesid Alena Bohaneva ja Mare Kõiva.

22. septembril pidas Juras Paciupa Välisministeeriumi arengu- ja humanitaarabi programmi ning Euroopa Regionaalarengu Fondi (Eesti-uuringute Tippkeskus) toel ettekande "Kuidas on moodustatud rahvalik värss? Mõningaid teoreetilisi, metodoloogilisi ja tekstoloogilisi probleeme valgevene materjali põhjal”.

3. oktoobril pidas Liisi Laineste Eesti-uuringute Tippkeskuse nüüdiskultuuri töörühma seminaril ettekande "Big noses and small rams: Metaphor use in Estonian conversations".

10. oktoobri teisipäevaseminari teemaks oli pärimusteadmiste olulisus looduskaitses ja ökoloogias. Aveliina Helm andis ülevaate uurimustest, mis on sidunud inimese ajaloolist tegevust koosluste ökoloogia ja kaitsega ning arutleb koos kuulajatega pärimusteadmise rakendamise võimalustest looduse uurimisel ja kaitsel.

30. oktoobril esines Eesti Rahvaluule Arhiivi venekeelsele kogule pühendatud seminaril Alaksei Hlushko, kes jagas võrdleva uurimise kogemusi tööst Eesti Kirjandusmuuseumis leiduvate venekeelsete rahvaluulematerjalidega. Teadusvahetuse koostööprojekti rahastab Välisministeerium arengu- ja humanitaarabi vahenditest, seda toetavad Euroopa Regionaalarengu Fond (Eesti-uuringute Tippkeskus) ja Eesti Teadusagentuuri IUT 22-5.

21. novembril pidas Alena Leshkevich ettekande "Valgevene vastlanädal tänapäeval ja selle lokaalsed erijooned".

28. novembri seminaril kõneles Aimar Ventsel: "Mõtteid välitöömaterjalide interpreteerimisest". Seminari toetasid Euroopa Regionaalarengu Fond (Eesti-uuringute Tippkeskus) ja Eesti Teadusagentuuri IUT 22-5.

5. detsembril kõneles Sloveeni antropoloog, Ljubljana ülikooli doktorant Daša Ličen: "Habsburgi köögi taasavastamine 21. sajandi Triestes". Skype'i vahendusel korraldatud seminari modereeris Saša Babič, seminari toetasid Euroopa Regionaalarengu Fond (Eesti-uuringute Tippkeskus) ja Eesti Teadusagentuuri IUT 22-5.

Asta Niinemets 


\section{Tartu Ülikooli eesti ja võrdleva rahvaluule osakonnas}

22. septembril pidas prof dr Sadhana Naithani (Jawaharlal Nehru Ülikool, New Delhi) loengu "Magic, Wonder \& Ethics".

3. oktoobril pidas prof dr Nira Yuval-Davis (Ida-Londoni Ülikool) külalisloengu "Everyday bordering, autochthonic politics and the double crisis of governability and governmentality".

4.-6. oktoobrini toimus TÜ Narva kolledžis 7. rahvusvaheline noorte folkloristide konverents "Kuulumise ja eristumise praktikad" (korraldajad TÜ eesti ja võrdleva rahvaluule osakond ja kultuuriteaduste ja kunstide doktorikool, toetas Euroopa Liidu Regionaalarengu Fond (Tartu Ülikooli ASTRA projekt PER ASPERA).

6. novembril pidas prof Per Kværne (Oslo Ülikool) loengu "Buddhist Surrealists from Bengal".

7. novembril pidasid prof Amy Allocco ja prof Brian Pennington (Elon University, USA) ühisloengu "Innovating Hindu Folk Practices, North and South: A Himalayan Healer and Tamil Snake Worship" (Hinduistliku rahvausundi uuendusi Põhja- ja Lõuna-Indiast: Himaalaja ravitseja ja Tamili maokultus).

8.-10. novembrini toimus konverents "Jumalad, vaimud ja deemonid Aasia rahvapärastes uskumustes ning rituaalides”. Konverentsi korraldas TÜ eesti ja võrdleva rahvaluule osakond koostöös Napoli L'Orientale Ülikooli Aasia, Aafrika ja Vahemeremaade osakonna ning TÜ Aasia keskusega.

10. oktoobril algas ERMi Hurda saalis Kirde-India põliskultuuride loengusari, mis tutvustab India kirdeosas elavaid põlisrahvaid ja -kultuure kaheksast osariigist, kus elab kokku ligikaudu 45 miljonit inimest. Indias on orienteeruvalt 214 erinevat põlisrahvast, kellel on oma keel ja teistest erinevad kultuurilised ja religioossed praktikad. Sarja eesmärgiks on tutvustada ja esitleda India kirdeosa etnilisi vähemusrühmi Eestis.

Ettekande Kirde-India põlisrahvastest pidas TÜ professor Ülo Valkja esilinastusele tuli khasi hõimu käsitlev etnograafiline film "Minu nimi on Eeooow" (režissöör Oinam Doren).

Loengusari on sündinud koostöös Eesti Rahva Muuseumi ja Tartu Ülikooli eesti ja võrdleva rahvaluule osakonna ning Aasia keskusega.

13. novembril toimus Tartu Ülikooli peahoones senati saalis sümpoosion "Humanitaaria rahvusvahelises ja rahvuslikus teadusruumis", millega tähistati ajakirja Journal of Ethnology and Folkloristics 10. sünnipäeva.

14. novembril pidas professor Simon Bronner (The Pennsylvania State University, USA) ingliskeelse loengu "Folkloor kui praktika".

29. novembril pidas Mihály Hoppál Ungarist seoses Tartu Ülikooli folkloristika ja semiootika audoktoriks kuulutamisega loengu "Influence of the Tartu-Moscow semiotic school on Hungarian ethnosemiotics". 


\section{Kaitstud doktoritööd}

Nikolai Anisimov kaitses 10. novembril doktoriväitekirja “Диалог миров в матрице коммуникативного поведения удмуртов” (Maailmadevaheline dialoog udmurtide kommunikatiivse käitumise matriitsis, juhendajad TÜ vanemteadur Madis Arukask ja Urmurdi Riikliku Ülikooli dotsent Galina Gluhova; oponendid dr Aado Lintrop, Eesti Kirjandusmuuseum ja dr Jelena Popova, Udmurdi Ajaloo, Keele ja Kirjanduse Instituut (Venemaa)).

Tatjana Alõbina (Tatyana Alybina) kaitses 10. novembril etnoloogia erialal doktoritööd “Трансформация марийской религиозной традиции в постсоветский период” (Mari religioossete traditsioonide muutused nõukogujärgsel ajal; juhendajad prof Art Leete (TÜ) ja prof Galina Purõnõtsheva (Volga Riiklik Tehnoloogiaülikool, Venemaa); oponendid dr Eva Toulouze ja dr Tatiana Minnijakhmetova (Innsbrucki Ülikool, Šveits)).

\section{Kaitstud magistritöö}

Laura Mäemets kaitses 31. augustil Tartu Ülikoolis magistritööd "Pelli pärimus Mulgimaal: traditsioon, tuntus ja tähendus” (juhendaja dotsent Ergo-Hart Västrik, oponent teadur Kristel Kivari).

Liilia Laaneman

\section{NEWS IN BRIEF}

\section{Birthday greetings!}

Olli (Olga Ottilie) Kõiva (85), Tiiu Salasoo (85), Mall Hiiemäe (80), Luule Krikmann (80), Kristi Salve (75), Igor Tõnurist (70), Rein Saukas (70), Janīna Kursīte (65), Merike Kiipus (60), Vilve Asmer (60), Ülo Valk (55), Mari Sarv (45), Andreas Kalkun (40)

\section{Calendar}

A brief summary of the events of Estonian folklorists from July 2017 to December 2017. 